\title{
Two novel mutations: 5108delAG and 5816insG in the NF1 gene detected by SSCP analysis
}

Jun Zhong, Roland Splegel*, Eugen Boltshauser' and Werner Schmld

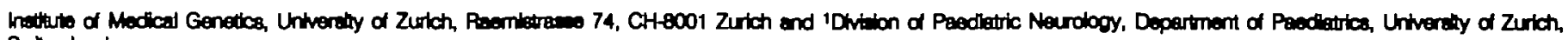
Swizertand

Received May 26, 1993; Revised and Accepted July 14, 1993

Neurofibromatosis type I (NF1) is one of the most common autosomal dominant disorders in man and is characterized by cafe-cu-lait spots, multiple neurofibromas, iris hamartomas (Lisch nodules), orthopedic problems, learning disabilities, and an increased risk of malignancy. The NF1 gene consists of 49 exons, and extends over a genomic distance of approximately $300 \mathbf{~ k b}$ on human chromosome 17q11.2. It encodes for neurofibromin, a 2818 amino acid protein which is capable of down-regulating ras by stimulating its intrinsic GTPase activity $(1-4)$. The mutation rate for NF1 is high (1 in 10000 ), and about half of all cases are due to new mutations (5). In order to characterize the individual mutations in the NF1 gene, we investigated genomic DNA samples from 82 Swiss NF1 families (including 31 sporadic cases) by single strand conformation polymorphism (SSCP) analysis. Here we describe two novel mutations found in exons 28 and 31 of the NF1 gene. The other 80 families investigated for these two exons showed no SSCP alterations.

Exon 28 and exon 31 were amplified by the polymerase chain reation (PCR) using primers described by Upadhyaya et al. (5) and Cawthon et al. (2) on a Perkin Elmer 9600 thermal cycler. For exon 28, PCR was performed at $94^{\circ} \mathrm{C}$ for $1 \mathrm{~min}$ followed by $30 \mathrm{cycles}$ at $94^{\circ} \mathrm{C} 30 \mathrm{sec}, 52^{\circ} \mathrm{C} 30 \mathrm{sec}$, and $72^{\circ} \mathrm{C} 30 \mathrm{sec}$, with final elongation at $72^{\circ} \mathrm{C}$ for $10 \mathrm{~min}$. For exon 31 , the amplification conditions were: $94^{\circ} \mathrm{C}$ for $1 \mathrm{~min}$, then 30 cycles at $94^{\circ} \mathrm{C} 30 \mathrm{sec}, 50^{\circ} \mathrm{C} 15 \mathrm{sec}, 72^{\circ} \mathrm{C} 15 \mathrm{sec}$, with final elongation at $72^{\circ} \mathrm{C}$ for $10 \mathrm{~min}$. SSCP was performed following the method of Yap et al. (6): Briefly, 2-10 $\mu$ l of PCR product was adjusted to a total volume of $10 \mu \mathrm{l}$ with water, incubated at $42^{\circ} \mathrm{C}$ for 10 min after addition of $1 \mu \mathrm{l} 0.5 \mathrm{M} \mathrm{NaOH}, 10 \mathrm{mM}$ EDTA. $1 \mu \mathrm{l}$ of formamide containing $0.5 \%$ bromophenol blue and $0.5 \%$ xylene cyanol was added just before loading. Electrophoresis was carried out on 5-6\% polyacrylamide gels either with $10 \%$ glycerol at $20^{\circ} \mathrm{C}$ or without glycerol at $4^{\circ} \mathrm{C}$. The gels were run at $400-500$ volts $(20-25 \mathrm{~V} / \mathrm{cm})$ for 4 hours. Bands were visualized by silver staining. Double-stranded PCR products purifed by agarose gel electrophoresis were sequenced using Sequenase version 2.0 (USB) under the conditions described by Casanova et al. (7).

Every affected individual in NF1 family 15 showed one aberrant single strand band and one aberrant double strand band in exon 28 by SSCP analysis. Direct sequencing of the PCRproduct revealed an 'AG' deletion at codon 1703 (5108delAG). This deletion leads to a shift of the reading frame, creates a stop codon 93 bases downstream, and thus should result in a truncated gene product of 1733 amino acids (see Figure 1). One aberrant single strand band segregating with the disease phenotype in NF1 family 72 was detected in exon 31 by SSCP analysis. Sequence analysis revealed a guanine insertion at codon 1939 (5816insG), which also leads to a frameshift resulting in a stop codon 7 bases downstream, predicting a truncated protein of 1941 amino acids (see Figure 2). This mutation abolishes a CviR I restriction site.

The adult patients 49 and 51 of NF1 family 15 suffer from a very severe dermal form of NF1 with extensive involvement of trunk, neck and face. Individual 47 of the same family developed multiple dermal neurofibromas before puberty, and has left-sided tibia pseudoarthrosis and one plexiform neurorofibroma causing extreme hypertrophy of the right foot. All patients present with mild to severe funnel chest. Common clinical features shared by the patients of NF1 family 72 include multiple café-au-lait spots, and dermal and subcutaneous neurofibromas. In addition, patient 332 and her affected brother, who has not been investigated by molecular studies, suffer from severe scoliosis. In patients 328 and 326, no spine deformity has been found.

Only a few mutations have been previously identified in the NF1 gene. Of the mutations presented here, 5108delAG is associated with very severe dermal manifestations and funnel chest in NF1 family 15, and 5816insG with severe scoliosis in 2 out of 4 affected members from NF1 family 72. Interestingly, three other previously reported families carrying nonsense mutations in exon 31 also exhibited scoliosis $(8,9)$, suggesting a possible correlation between this clinical feature and these particular mutations. It will be important to identify a larger number of mutations in NF1 patients in order to clarify the phenotypic consequences of mutations in specific gene regions. The identification of these mutations is also helpful for genetic counselling and diagnosis of affected individuals and asymptomatic gene carriers in the respective families.

\section{ACKNOWLEDGEMENTS}

We would like to thenk Dr Albert Schined and Dr Wendy Robineon for belpful commente on this manuscrip.

\section{REFERENCES}

1. Vidoctil,D., Buctberg,A.M., Xu,G., Corthon,R, Steven,J., Wolf, R.K., Culver,M., Curey,J.C., Copelend,N.G., Jenkins,N.A., White,R. and O'Connell,P. (1990) Cell 62, 187-192.

2. Cawthon,R.M., Wciss, R., Xu,G., Vittoctil,D., Culver,M., Stevens,J., Robertson,M., Dum, D., Gestetend, R, O'Comell,P., and White,R. (1990) Cell 62, 193-201. 


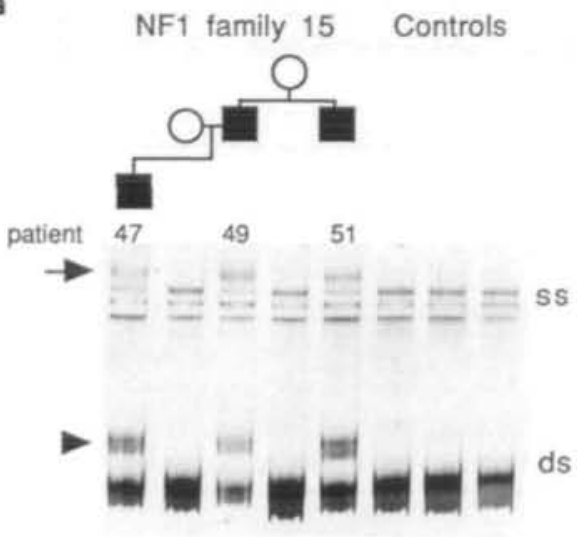

b

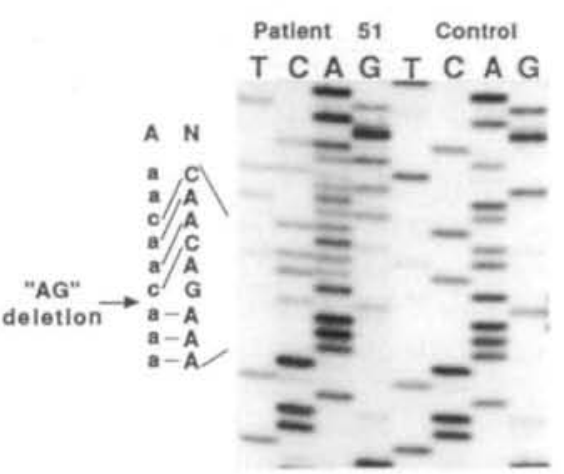

C

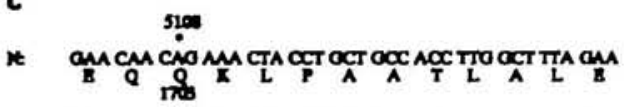

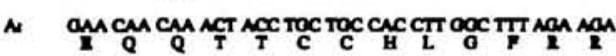

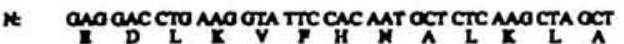

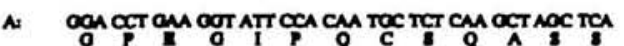

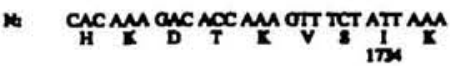

N CMAGA CACCMANT TTCTAT TMA

F-gure 1. a) SSCP antyris of exon 28 in NF1 family 15 and controls. The arrow indicates the sberren singlo-stranded (ev) DNA band, the arrow bead shows the aberrat doublo-atinded (ds) DNA band. b) Partial sequecce of exon 28 in patient 51 and control. The potition of the 'AG' deletion is incicated by an arrow. The amples were sequenced from the 3' dfrection. c) Nucleotide and amino scid sequence information showing the normal (N) and mutnted (A) expence. The deletion of nuclectides 5108 and 5109 leads to a thitt of the reating finme revulting in 30 altered amino actds and a rop codon at amino acid 1734 .

3. Wallece,M.R, Marchuk,D.A., Andersen,L.B., Letcher,R, Odeh,H.M., Senlino,A.M., Fountain,J.W., Brereton,A., Nicholnon,J., Mitchell,A.L., Brownetein,B.H., and Collins,F.S. (1990) Sclence 209, 181-186.

4. Marchulk,D.A., Smiltno,A.M., Trvaltool,R., Swaroop,M., Wallece,M.R. Andernen,L.B., Michell,A.L., Gurman,D.H., Boginit,M. and Collins,F.S. (1991) Genomics 11, 931-940.

5. Upedhyaya,M., Shen,M., Cherrymon,A., Farnham,J., Maynard,J., Hueco, S.M. and Harper,P.S. (1992) Hum. Mol. Gene. 1, 735-740.

6. Yap,E.P.H. and MoGee,J. (1992) Thends Gener. 8, 49.

7. Camove,J.-L, Pannetier,C., Jnulin,C. and Kouriliky,P. (1990) Nucleic Acids Res. 18, 4028.

8. Atnsworth,P J., Rodenhiver,D.I. and Costa,M.T. (1993) Hum. Gener. 91, $151-156$.

9. Entivill,X., Lamaro,C., Canls, T. and Ravella,A. (1991) Hwon. Ganer. 88, $185-188$. a

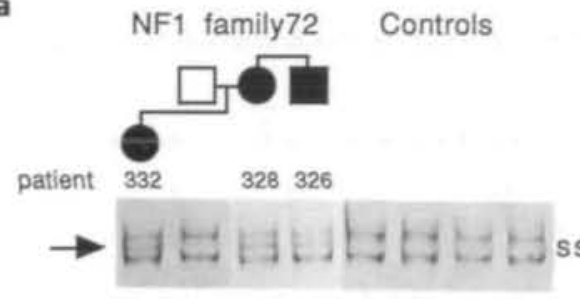

b
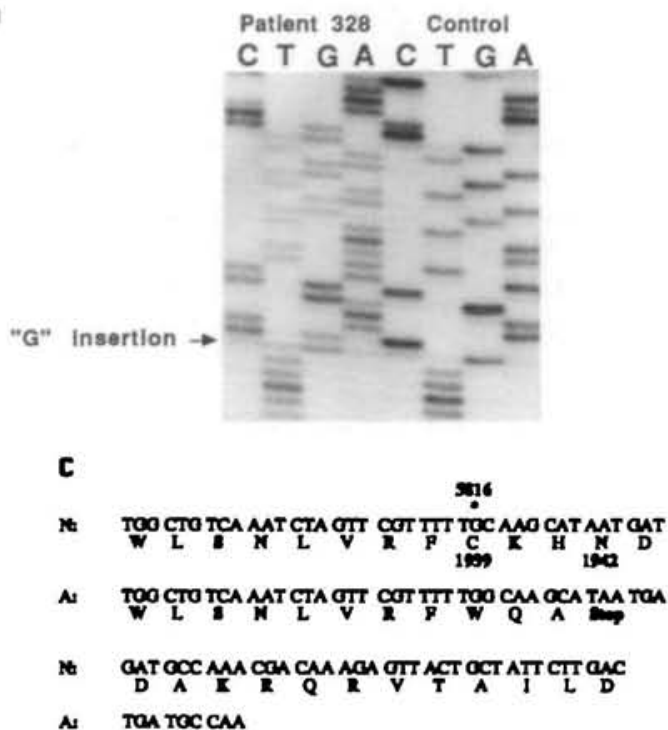

Fipre 2. a) SSCP antyias of exon 31 in NP1 finily 72 and controts. The abernant single-etranded (a) DNA band is indicated by an arrow. b) Partinl secuence of exon 31 thowing a guxnine insertion in petient 328. The normal sequence is thown at the right. The simples were sequenced from the 5' direction. c) Comparteon of the the normal (N) and mututed (A) sequence shows that the guanine insertion a nucleotide 5816 leads to alternitions of three amino seids and creates a stop codon at amino acid 1942. 